\title{
KOBIETY ARENY. STATUS SPOŁECZNY GLADIATOREK I TOREADOREK
}

\author{
Dawid Barbarzak*
}

\begin{abstract}
The paper tries to compare the social status which was assigned to female-gladiators in ancient Rome and to female-bullfighters (toreras) in modern Spain. The analysis of some written, archeological and plastic sources reveals their presence and social perception over the centuries. In the reports of ancient and modern authors, we can find different opinions about the phenomenon: they range from admiration for fighting skills or female beauty (Martial, Statius, Goya, Daza) to strong criticism (Petronius, Propertius, Juvenal, Sarmiento, Llorens) for mixing gender roles and posing a threat to social, religious or moral order. I also compare some legal regulations which excluded women from active participation in Roman games and Spanish bullfighting.
\end{abstract}

Keywords: bullfighting, Roman games, sport, gender studies, social status.

Słowa kluczowe: corrida, igrzyska, sport, gender studies, status społeczny.

Areny, zarówno te w rozsianych po Imperium Romanum amfiteatrach, jak i te w działających do dziś hiszpańskich czy latynoamerykańskich plazas de toros, kojarzą się zwykle z typowo męską aktywnością. Obecność kobiet, nie licząc może roli ofiar egzekucji ad bestias, wydaje się sprowadzać do biernej obserwacji

\footnotetext{
* Uniwersytet im. Adama Mickiewicza w Poznaniu, Wydział Filologii Polskiej i Klasycznej, Instytut Filologii Klasycznej, ul. Fredry 10, 61-701 Poznań, barbarzak.dawid@gmail.com.
} 
widowiska. Jednakże, jak dowiedli badacze starożytnych igrzysk i historycy tauromachii, zdarzało się, że kobiety przyjmowały i dalej przyjmują rolę czynnych uczestniczek tych z pozoru męskich widowisk ${ }^{1}$. Celem artykułu jest próba uchwycenia statusu, jaki przypisywało im społeczeństwo, odpowiednio rzymskie i hiszpańskie.

Pomimo wieków, które upłynęły odkąd ostatni gladiatorzy opuścili amfiteatry, aż po wykształcenie się corridy de toros w nowożytnej Hiszpanii, status gladiatorek i toreadorek ${ }^{2}$ wydaje się pod wieloma względami podobny. Ich obecność na arenie była w obu kulturach zjawiskiem stosunkowo niezwykłym i rzadkim, często łamiącym pewne ustalone normy i budzącym ambiwalentne uczucia: od podziwu po niechęć. Opinii na temat wojujących na arenie kobiet nie szczędzili ani rzymscy poeci i historycy, ani hiszpańscy uczeni, publicyści czy duchowni. Co więcej, zarówno rzymskie, jak i hiszpańskie prawo wprowadziło odpowiednie regulacje, mające ograniczać czy wręcz wykluczać kobiety z aktywnego udziału w walce. Wszystko to skłoniło mnie do podjęcia komparatystycznej analizy, w której przyjrzę się rzymskim i hiszpańskim źródłom, zarówno tym krytykującym, jak i wyrażającym podziw dla kobiet areny.

1 Jeśli chodzi o igrzyska, na potrzeby niniejszego artykułu korzystałem zwłaszcza z: Brunet (2014); McCullough (2008); Murray (2003); Pastor, Mañas (2012); Coleman (2000). Z opracowań o roli kobiet w corridzie warto wymienić: Feiner (2017); Feiner (1995); Schubert (1999: 114 i n.). Inne prace znajdują się w bibliografii i przypisach.

$2 \mathrm{~W}$ źródłach rzymskich nie pojawia się osobne określenie na kobietę-gladiatora: występujące w opracowaniach gladiatrix zostało ukute przez badaczy. Na potrzeby artykułu przyjmuję określenie "gladiatorka", od męskiej nazwy "gladiator" (por. hiszp. gladiadora, ang. female-gladiator). Określenie venatrix (łowczyni), pojawia się w odniesieniu do Diany, bogini łowów (Verg. A. 1, 319; 9, 178 Heyne; Ovid. Meth. 2.454; 2.492; Ambros. Virg. 3.2.6). Z kolei w języku hiszpańskim dla terminu el torero powstała analogicznie żeńska forma la torera. Trzymając się jednak polskiej tradycji słowa „toreador”, będę używał określenia „toreadorka”. 


\section{1. \\ Źródta}

Walki gladiatorów wywodzić się miały z etruskich rytuałów funeralnych, podczas których jeńcy wojenni toczyli walkę na śmierć i życie nad grobem uznanego wojownika (Brunet, 2014: 484; Pastor, Mañas, 2012: 129). Atenajos (Ath 4.153f) przekazuje za Mikołajem z Damaszku, że w owych munera uczestniczyli nie tylko mężczyźni: „Zdarzało się, że któryś z nich wskazał w swym testamencie, że najpiękniejsze kobiety, które kupił, miały z sobą walczyć, a inny mógł wskazać nawet, że mają to zrobić jego dwaj ulubieni chłopcy"3. Większość źródeł pisanych, pochodzących wyłącznie z epoki cesarstwa, wskazuje, że występy gladiatorek były rozrywką rzadką, organizowaną niemal wyłącznie przez cesarzy ${ }^{4}$. Wzmiankom towarzyszą znamienne przymiotniki wyrażające wyjątkowość i luksus. Munera zorganizowane przez Nerona Tacyt określa jako „magnifica et sumptuosa” (Ann. 15.32). Kasjusz Dion wśród urządzanych przez Domicjana uczt i zabaw, wymienia i takie: „Często organizował igrzyska także nocą, a czasem kazał kobietom i karłom walczyć przeciwko sobie" (Cass. Dio 67.8.4) ${ }^{5}$. Fakt ten potwierdza również Swetoniusz (Suet. Dom. 4.1): „Nam venationes gladiatoresque et noctibus ad lychnuchos, nec virorum modo pugnas, sed et feminarum"6. Kolejne źródła wykażą przypadki udziału kobiet w walkach przeciw kobietom, ale także dzikim zwierzętom (łac. venationes), co w zestawieniu $\mathrm{z}$ corridą wydaje się istotne i interesujące.

3 Cyt. za: Athenaeus, 1928: 201, tłum. D. B. Por. Grant 1971: 14.

4 Patronat wiązał się z osobami Nerona (Cass. Dio 62.17.3; Tac. Ann. 14.14 i 15.32; Suet. Nero 4), Tytusa (Mart. Spect. 6) czy Domicjana (Stat. Silv. 1.6.51; Cass. Dio 67.8.4; Suet. Dom. 4.1). Część igrzysk organizowano prywatnie (Petron. Sat. 45.738; CIL IX, 2237, relief z Halikarnasu, przyp. 10).

5 Cyt. za: Kasjusz Dion 1925: 336, tłum. D. B.

6 „Walki z dzikimi zwierzętami i walki gladiatorów urządzał nawet nocami przy pochodniach; bitwy nie tylko mężczyzn, lecz także kobiet”, tłum. J. Niemirska-Pliszczyńska (Swetoniusz, 1965: 441). 
Niektóre z igrzysk organizowano prywatnym sumptem. Pochodząca z II wieku inskrypcja z Ostii (CIL IX, 2237) upamiętnia niejakiego Hostilianusa, który „primus omnium ab urbe condita ludus cum mulieres ad ferrum dedit". Zagadkowe ad ferrum oznaczać może karę śmierci, zesłanie jakichś kobiet „pod miecz"7. Według innych interpretacji, może być to upamiętnienie prywatnych igrzysk, których atrakcją były kobiece walki „na miecze". Mielibyśmy tutaj dowód uznania Rzymian dla wojujących kobiet oraz chęć uwiecznienia tego rzadkiego wydarzenia. Nieco o tym zjawisku mówią nam źródła archeologiczne. O ile jednak wizerunki gladiatorów czy łowców (venatores) są popularnym motywem rzymskich mozaik czy elementem dekoracyjnym lampek oliwnych, o tyle dysponujemy jedynie dwoma artefaktami ozdobionymi wizerunkami gladiatorek. Pierwszym jest tabliczka z Halikarnasu (obecnie Bodrum), na której widnieją dwie uzbrojone postaci kobiece (Coleman, 2000: 498). Drugi to znajdująca się w muzeum w Hamburgu brązowa statuetka półnagiej gladiatorki, triumfalnie wznoszącej krótki, zakrzywiony miecz ${ }^{8}$. Trzecim śladem archeologicznym jest pochówek kobiecy z Londynu, najprawdopodobniej błędnie utożsamiany z pochówkiem gladiatorki ze względu na odnalezioną w wyposażeniu grobowym lampkę oliwną z wizerunkiem gladiatora ${ }^{9}$. Te i inne źródła omówimy w dalszej kolejności w kontekście opinii o gladiatorkach.

Choć rzymskie igrzyska praktykowano także w iberyjskich amfiteatrach, z braku archeologicznych czy pisemnych

7 Inskrypcja jest częściowo rekonstruowana (Brunet, 2014: 482).

8 Wcześniejsze interpretacje zakładały, że ów miecz to strigilis, przyrząd higieniczny do czyszczenia ciała. Więcej o tym artefakcie zob. Mañas, 2011.

9 Odkrycie wzbudziło dużą sensację, jednak opinia jakoby odnalezione szczątki należeć miały do gladiatorki jest krytykowana. W okolicy nekropoli znajdował się amfiteatr, lecz szkielet nie nosi typowych dla kości gladiatorów śladów uszkodzeń, jak w Efezie, gdzie badania prowadzili Kanz i Grossschmidt w 2005 roku (Brunet, 2014: 485). Podejrzewa się, że mogła być to żona gladiatora (Alberge, 2000: 3; Pringle, Broad, 2001). 
źródeł nie wiemy, czy występowały tam gladiatorki. Źródła dotyczące corridy są naturalnie o wiele obfitsze niż te starorzymskie, z konieczności korzystać będę więc z najbardziej reprezentatywnych. Są wśród nich opracowania o historii tauromachii (powstające od XVIII wieku do dziś), materiały plastyczne (obrazy, grafiki, fotografie), teksty publicystyczne, wypowiedzi samych toreadorów, nagrania wideo i inne. Corrida de toros, choć pod wieloma względami przypomina dawne rzymskie venationes, wyrosła na gruncie średniowiecznych turniejów rycerskich ${ }^{10}$. Bohaterami tej tauromachicznej sztuki, inaczej niż w Rzymie, aż do XVIII wieku, byli arystokraci. Konne potyczki z bykiem toczone przez hiszpańskich notabli, a nawet królów, odbywały się na placach miejskich. Zmagania te przez wieki były formą emanacji męskiej, arystokratycznej odwagi. Kobiety zaś, spoczywające w lożach czy też stojące w tłumie (zależnie od stanu), przyjmowały przez wieki głównie rolę obserwatorek. Na pewne odstępstwa wskazuje wizerunek z klasztoru Santo Domingo de Silos (Burgos). Na średniowiecznym malunku z XIV wieku widzimy kobietę drażniącą harpunem młodego byka (Mateo Gómez, 2003: 266). W wieku XVIII jed nak szlachta straciła zainteresowanie corridą, co pozwoliło na rozwój tak zwanej corridy ludowej: od tego czasu większą rolę zyska walka piesza (toreo a pie). Powstają wówczas inspirowane amfiteatrami plazas de toros, na których pojawiać się będą osoby z niższych stanów społecznych, wśród nich także sporadycznie kobiety. Wiek XIX to w Hiszpanii czas rozkwitu drużyn złożonych wyłącznie z kobiet, które stają się wówczas niemałą atrakcją. Wśród podziwu rozbrzmiewają jednak coraz częstsze głosy krytyki, które swą kulminację osiągną w 1908 oraz w czasie dyktatury Franco, gdy nie tylko opinia publiczna, ale i prawo zablokuje toreadorkom drogę na arenę. Regulacje prawne omówimy na końcu naszych rozważań. Wcześniej jednak przyjrzymy się przykładom podziwu i krytyki wobec kobiet areny.

10 Ogólne porównanie igrzysk rzymskich i corridy omawiam w osobnym artykule (Barbarzak, 2017). 


\section{Gtosy podziwu}

Obecność kobiet na rzymskich i hiszpańskich arenach była zjawiskiem na tyle rzadkim, że większość źródeł pisanych wraz z informacją wyraża jednocześnie opinię o tych zdarzeniach. Część osądów jest pozytywna. Spotykamy trzy typy reakcji: zachwyt nad novum samego wydarzenia, podziw dla sprawności fizycznej kobiet oraz fascynacja bijącym od nich erotyzmem (często idącym w parze z realną bądź wykreowaną egzotyką). Zadziwiony nowością zjawiska wydaje się poeta Marcjalis w Księdze widowisk. Ten zbiór epigramatów, spisanych dla uczczenia igrzysk urządzonych w Koloseum za Tytusa i Domicjana, wyraźnie sugeruje obecność kobiet na arenie (Mart. Spect. 6):

Belliger invictis quod Mars tibi servit in armis, non satis est, Caesar, servit et ipsa Venus (Martialis, 2018)11.

Obecność gladiatorek na arenie wyraża tu symbolicznie postać ich patronki, Wenus, $\mathrm{w}$ analogii do Marsa, patrona gladiatorów. O tym, że za tym symbolem kryją się prawdziwe uczestniczki igrzysk, świadczy cytowana już informacja Swetoniusza z żywotu Domicjana (Suet. Dom. 4.1), a także kolejny epigramat Marcjalisa (Spect. 6b). Poeta mówi w nim wprost o łowczyni walczącej z lwem, określając ową venatrix mianem „kobiecego Marsa”:

Prostratum vasta Nemees in valle leonem nobile et Herculeum fama canebat opus.

Prisca fides taceat: nam post tua munera, Caesar, hoc iam femineo Marte fatemur agi (Martialis, 2018) ${ }^{12}$.

11 „Nie dość, że Mars wojowniczy niezwyciężonym orężem/ służy ci, sama Wenus, Cezarze, służy ci też!", tłum. K. Różycka-Tomaszuk (Marcjalis, 2015: 85).

12 „O lwie, co padł w rozległej Nemei dolinie,/ baśń niosła znana, sławiąc Herkulesa czyn./ Niech milczą stare legendy - po twoich igrzyskach, Cezarze,/ już wiemy, że takiej sztuki niewieścia dokona dłoń”, tłum. K. Różycka-Tomaszuk (Marcjalis, 2015: 86). 
Marcjalis pisał oczywiście ku chwale cesarza, nie zaś samych gladiatorów czy gladiatorek. Te ostatnie jednak chwały imperatorowi nie ujmują, przeciwnie, dodają igrzyskom splendoru i wyjątkowości, nie stając się w żadnym razie obiektem kpiny poety, skłonnego przecież do satyry społecznej. Innym poetą wyrażającym zachwyt jest Stacjusz. W swoich Silvae (1.6.51), będących panegirykiem na cześć Domicjana, opisuje obchody Saturnaliów. Podczas świąt w barwnym orszaku kroczą uzbrojone kobiety:

Hos inter fremitus novosque luxus

spectandi levis effugit voluptas:

stat sexus rudis, insciusque ferri

ut pugnas capit improbus viriles!

credas ad Tanain ferumque Phasim

Thermodontiacas calere turmas (Statius, 2018) ${ }^{13}$.

Opinia autora wydaje się ambiwalentna. Z jednej strony mówi o powiewie nowości i przyjemności (voluptas), jaką czerpać można $\mathrm{z}$ widoku wojowniczek. $\mathrm{Z}$ drugiej strony autor widzi w tym naśladownictwie męskich zajęć pewną bezczelność (improbus). Sztuka wojenna przynależała mężczyznom (pugnae viriles), zaś kobiety były „nienawykłe do miecza” (insciusque ferri). Dlatego też te przebrane kobiety z orszaku przywodzą poecie na myśl nie rzeczywiste Rzymianki, lecz plemię im obce, mityczne Amazonki (Brunet, 2014: 486). Co więcej, tuż za Amazonkami Stacjusz stawia w pochodzie waleczne karły, z których śmieją się Mars i Virtus. Czy ich śmiech dotyczy również idących przed nimi kobiet? Przytoczony przez Diona Kasjusza fragment o urządzanych przez Domicjana walkach kobiet i karłów (Cass. Dio 67.8.4.) każe podejrzewać, że jedno i drugie pojmowano jako dziwactwo, parodię męskich walk. Mogły one zadziwiać, ale i wzbudzać podziw, wywoływać śmiech, niekoniecznie przecież szyderczy.

13 „Pośród gwaru i wystawnych nowości migocze rozkosz spektaklu: płeć dzika i nieznająca miecza staje bezczelnie do męskich walk. Uwierzyłbyś, że to oddziały z Termodontu, całe w ferworze, nad Donem lub dziką Fasis” (tłum. D. B.). 
W bardzo podobnym, karnawałowym duchu odbywać się musiały w Hiszpanii dziwiętnastowieczne mojigangas. Był to rodzaj teatralnej farsy, podczas której kobiety parodiowały walki z byka$\mathrm{mi}^{14}$. We współczesnej corridzie toreadorzy działają zwykle w ramach cuadrillas - kilkuosobowych drużyn, na które składają się piesi i konni toreadorzy oraz mistrz (matador), który ma stoczyć finałową walkę. W XIX wieku bardzo popularne stały się zespoły kobiece. Hiszpańskie areny wręcz rywalizowały o kontrakt z katalońską drużyną „Las Noyas”, złożoną z wybitnych ówczesnych toreadorek. Twórca i manager drużyny Mariano Armengol, podobnie jak Stacjusz, pełen był a mbiwalencji. Z jednej strony krytykował udział kobiet w corridzie, jak wielu innych znawców tauromachii. $Z$ drugiej jednak był całkowicie świadom zysku, jaki przynosiła mu sprzedaż biletów na tego typu wydarzenia, będące w Hiszpanii nowością (Schubert, 1999: 114).

Podziw dla niektórych gladiatorek czy toreadorek wynikał jednak również z ich realnych umiejętności. Na wspomnianej już tabliczce z Halikarnasu (II wiek n.e.) nad wizerunkiem gladiatorek widnieje „apeluthesan” (gr. „zostały wyzwolone”). Sugeruje to, że wojowniczki, być może w dowód uznania za wyrównaną walkę, uzyskały wolność. O remisie świadczy również gest odrzucenia na ziemię hełmów. Samo zresztą ufundowanie reliefu przez organizatora igrzysk to znak uznania dla kobiet o niskim przecież statusie społecznym. Znaczyłoby to, że sexus rudis nie zawsze był inscius ferri, jak sugerował Stacjusz. W kontekście corridy również mamy do czynienia z podziwem dla umiejętności toreadorek. Pod koniec XVIII stulecia José Daza, autor historii tauromachii Precisos manejos, wymieniwszy dawne kobiety stające w szranki z bykami, uzna ich czyny za dowód prawdziwego męstwa, które przynosi chlubę hiszpańskiemu narodowi:

¡Aquí, valientes y esforzados españoles míos, es donde se consumaron todos los diques de la natural robustez o va-

14 Coello Ugalde (2013). Na myśl przychodzi też film Blancanieves (2012) w reżyserii Pabla Bergera, gdzie Królewna Śnieżka trafia nie do krasnoludków, a do drużyny karłów-toreadorów. 
lentía de nuestra nación! ¡Pues desde la cumbre de las más sublimes hasta los más profundos valles de las humildes esferas, se encuentran en el sexo femíneo de España tan varoniles y esforzados hechos! Capaces de emular a las más armadas huestes extranjeras. Que una sola española, en esta escuela de Marte, es de más importancia que todas las otras, que piensan en despicar su envidia con los torpes dicterios de que los españoles son unos bárbaros que luchan cuerpo a cuerpo con las mas horribles fieras, y las vencen (Daza, 1999: 103) ${ }^{15}$.

Uwagę zwraca porównanie męstwa toreadorek do Marsa, co przywodzi na myśl wyrażenie Mars femineus z cytowanego wcześniej epigramatu Marcjalisa. Z kolei powyższa wypowiedź Dazy to może najbardziej wzniosła pochwała, jaką kiedykolwiek napisano w Hiszpanii dla kobiet w kontekście corridy. Innym dowodem zachwytu twórców nad dawnymi toreadorkami jest rysunek Franscisca Goi z 1816 roku, przedstawiający La Pajuelerę, czyli Nicolasę Escamillę z Valdemoro, która zajmowała się corridą profesjonalnie, a swój pseudonim wzięła od produkowanych przez jej rodzinę pałeczek z siarki (pajuelas), którymi niegdyś dezynfekowano beczki. Na 22 grafice serii Tauromaquia widzimy ją na arenie, gdy konno i z piką w ręku odpiera nacierającego byka. Uznanie malarza dla jej postaci wyraża tytuł: Valor varonil de la célebre Pajuelera en la Plaza de Zaragoza - Męstwo stynnej Pajuelery na arenie Saragossy. Zauważmy, że już sam język sugeruje, iż odwaga i zdolności bitewne są typowo męskie. Przymiotnik varonil pochodzi od varón (oznaczającego mężczyznę, Diccionario de la lengua española de la Real Academia Española), podobnie jak łacińska virtus czyli „męstwo”, pokrewna jest słowu vir czyli "mężczyzna” (Korpanty, 2007: 650-651).

15 Daza opowiada o pewnej mniszce z okolic Sewilli, która zanim poszła do klasztoru, zwykła wchodzić $\mathrm{w}$ szranki z bykami, niejakiej Antonii Bretendona: wraz z kawalerami z Sewilli walczyła z bykami konno, oraz o córkach Piñeros z Kordoby; mówi również o szczególnym zapale do sztuki tauromachicznej w regionie Jerez de la Frontera i Medina Sidonia. 
Ważnym aspektem budzącym wśród Rzymian fascynację gladiatorkami była niewątpliwie związana z nimi egzotyka. Już Stacjuszowi idące w Saturnaliach kobiety skojarzyły się z Amazonkami. Na wspomnianej tabliczce z Halikarnasu uwieczniono także pseudonimy nadane gladiatorkom: „Achilla” (związek z heroiczną, męską siłą) oraz „A mazona” noszony przez postać ze wspomnianego reliefu $z$ Halikarnasu (II wiek n.e.). Ponieważ wojowniczki zdjęły hełmy, widzimy też ich krótko przystrzyżone włosy, na wzór Amazonek właśnie ${ }^{16}$. Musiała istnieć pewna fascynacja owym mieszaniem się żywiołu męskiego z kobiecym, skoro Neron kazał swym nałożnicom przebierać się za Amazonki i skracać włosy (Suet. Nero 44.1). Ten sam cesarz organizował walki wojowniczek z Etiopii (Cass. Dio 62.17.3), z egzotyką szedł więc w parze erotyzm. Zresztą także męskim gladiatorom kazano przybierać role barbarzyńskich wojowników (Trak, Samnita, Gall i tak dalej), tak więc i wojowniczki na tabliczce z Halikarnasu noszą zbroje typu Thrax. Musiało być to pociągające dla widzów.

Porównania do Amazonek będą żywe również w czasach nowożytnej corridy. Camilo José Cela w swej powieści Święty Kamil (1936), której akcja rozgrywa się w przededniu hiszpańskiej wojny domowej, tak opisze jedną z walczących konno toreadorek: „rejoneadora Beatriz Santullano, que monta a caballo como Dios, parece una centaura, no se dice centaura, bueno pues una amazona" (Cela, 1936). Niewątpliwie na podziw widzów dla kobiet areny wpływał też aspekt czysto erotyczny. Wiemy, że niektórym Rzymiankom podobali się gladiatorzy. Jeden z nich, imieniem Hermes, uchodził, według pewnego epigramatu, za „cura laborque ludiarum” (Mar. Ep. 5.24) - przedmiot trudów i starań aktorek (choć słowo ludia, może też oznaczać gladiatorkęl7). Możliwe, że mechanizm działał i w drugą stronę: gladiatorki pociągały mężczyzn. Erotyzm z pewnością łączył się z eksponowaną podczas walk nagością. Może to tłumaczyć organizację przez Domicjana walk kobiecych w po-

16 Mógł to być symbol niewoli lub świadome upozorowanie mitu (Pastor, Mañas, 2012: 140).

17 Hipotezy te są jednak rzadsze; ludia to raczej aktorka czy żona gladiatora (Jackson, 2000: 18). 
rze nocnej18. Wspomniana już figurka triumfującej gladiatorki z Hamburga również jest półnaga. Odbicie tych tendencji obecne jest we współczesnej popkulturze. Wystarczy spojrzeć na plakaty takich produkcji filmowych jak Le gladiatrici z 1963 czy The Arena z 1974 (film znany też jako Naked warriors), by zauważyć, że z tego erotycznego potencjału skorzystała współczesna kinematografia. Spektakularnym przedsięwzięciem była także muzyczna reklama Pepsi z 2004 roku, w której trzy gladiatorki zamiast walki na arenie zaśpiewały przebój We Will Rock You. W rolę cesarza wcielił się Enrique Iglesias, a nagrania dokonano w rzymskim Koloseum (Spanos, 2017). W amerykańskim wrestlingu, czy meksykańskiej lucha libre (WWE) zapaśniczkom również towarzyszy zwykle skąpy strój. Z kolei Las Cholitas z Boliwii, choć walczą w tradycyjnych spódnicach (polleras), to steatralizowana walka przysparza im wiele okazji do odkrywania się. Na marginesie można stwierdzić, że nieliczne w Rzymie walki kobiet nie tylko mają współczesny odpowiednik, lecz są dziś praktykowane na znacznie szerszą skalę.

Warto w tym miejscu powiedzieć kilka słów o stroju toreadorek. Kobiety obecnie walczące na hiszpańskich i latynoamerykańskich arenach noszą traje de luces, ukształtowany z końcem XVIII stulecia męski strój. Składają się na niego dopasowane spodnie i krótka marynarka, obficie przyozdobione złotymi cekinami. Jednak jeszcze na szkicu Gustava Doré Teresa Bolsi, torera andalouse z 1862 roku tytułowa toreadorka wiwatuje nad martwym bykiem w falbaniastej sukni z głębokim dekoltem. W jednej ręce dzierży szpadę i muletę, $\mathrm{w}$ drugiej charakterystyczny czarny beret (monetera), używany również współcześnie. W roku 1886 Dolores Sánchez „La Fragosa” jako pierwsza wdzieje męski traje de luces. Suknie były zresztą nie tylko mniej praktyczne, ale także budziły oburzenie. Zwracano uwagę, że kobiety, przewracając się na arenie albo skacząc przez ogrodzenie areny, ukazują „eso de enseñar la mujer lo que necesita estar cubierto", jak pisał malarz José Gutiérrez-Solana (Madariaga, Valbuena, 1976: 57-58). Jeszcze w roku 1907 zawstydziła go niejaka „Martina” na arenie w Santander. Na późniejszym obrazie Las señoritas toreras (1931),

18 Cass. Dio 67.8.4; por. Juv. 1.22; Stat. Silv. 1.6.51. 
tytułowe postaci artysta przedstawił, rzecz jasna, w spodniach. Ponieważ malarz tworzył także zmysłowe wizerunki kurtyzan, można przypuszczać, że zawstydzeniu związanemu z toreadorkami towarzyszyła ukryta fascynacja.

Są jednak źródła, które wydają się łączyć wymienione dotąd aspekty podziwu dla kobiet areny: ich umiejętności, fascynację erotyczną i egzotyczną nostalgię. Jedna z elegii Propercjusza wyraża podziw poety wobec spartańskiego wychowania dziewcząt (Eleg. III.14.1-34):

Multa tuae, Sparte, miramur iura palaestrae, sed mage virginei tot bona gymnasii, quod non infamis exercet corpore ludos inter luctantis nuda puella viros [...] et patitur duro vulnera pancratio [...] gyrum pulsat equis, niveum latus ense revincit, virgineumque cavo protegit aere caput, qualis Amazonidum nudatis bellica mammis Thermodontiacis turba lavatur aquis [...] quod si iura fores pugnasque imitata Laconum, carior hoc esses tu mihi, Roma, bono (Propercjusz, 1816: 291-292) $)^{19}$.

Skojarzenia ze spartańskim wychowaniem dziewcząt są wyjątkowo trwałe i pojawiają się także w kontekście corridy. Pewien korespondent w „Boletín de Loterías y de Toros” pisał, że na widowni chce widzieć przede wszystkim swoje rodaczki z Extremadury, u których delikatność łączy się ze spartańskim męstwem (Schubert, 1999: 114).

19 „Podziwiamy Sparto, wiele z twych obyczajów ćwiczebnych, ale najwięcej to dobrodziejstwo dziewczęcego gimnazjonu, gdzie naga dziewczyna może bez wstydu ćwiczyć swe ciało, między mężczyznami w zapasach [...] i znosić rany w twardym pięściarstwie [...] w okręgu jeździ konno, do śnieżnobiałego boku dopina miecz, a swą dziewiczą twarz przesłania brązowym hełmem, jak tłum wojowniczych Amazonek, co z nagimi piersiami kąpią się w wodach Termodontu [...] gdybyś naśladował lacedemońskie zwyczaje i walki, jakże byłbyś mi droższy, o Rzymie" (tłum. D. B.). 


\section{Głosy krytyki}

Krytyka podejmowana wobec kobiet areny również dotyczy kilku aspektów. Pierwsza grupa krytyków kładzie nacisk na utrzymanie tradycyjnej formy igrzysk czy corridy. Koncentruje się więc na samej arenie i broni „czystości” (to znaczy męskości) zjawiska. Innych bardziej dotyka kwestia zaburzenia społecznie (czy religijnie) przyjętych ról płciowych. Krytycy ci koncentrują się na kobiecej płci i jakoby przyrodzonych jej cechach czy obowiązkach związanych z prowadzeniem domu. W społeczeństwie rzymskim dodatkowym, jeśli nie najważniejszym, aspektem będzie stan społeczny, z jakiego pochodzi potencjalna gladiatorka.

Do autorów będących zwolennikami wyłącznie męskich gladiatorów zaliczyć możemy Juwenalisa. Wymieniając powody, dla których pisze satyry, wymienia Mewię, która z nagą piersią przebiła na arenie toskańskiego dzika: „Tuscum figat aprum et nuda teneat venabula mamma" (Sat. 1.22). To może jedyna znana z imienia rzymska venatrix, której rola przecież najbardziej przypomina walkę $\mathrm{z}$ bykiem. Juwenalis uznaje jednak taki widok za równie absurdalny, co żeniący się eunuch czy chłop równy bogactwem arystokracie, sądzi więc widocznie, że arena jest dla mężczyzn. Podobnie negatywną opinię wyraża Petroniusz w utworze Satyricon (45.7), wskazując na niejakiego Echiona. Ten bogaty organizator igrzysk wprost nie może doczekać się występu swojej „mulier essedaria” (Petronius, 2018), gladiatorki powożącej rydwanem ${ }^{20}$. Choć sam autor potępia tego typu innowacje, to przecież postać Echiona wykazuje pewne zafascynowanie podobnymi innowacjami na arenie i, być może, nie był w tym odosobniony. Podobne opinie możemy znaleźć u miłośników hiszpańskiej tauromachii. Przyzwyczajeni przez wieki do męskiej tylko areny, nie

20 Wskazuje się, że rydwan był dla gladiatorek pewnym wyrównaniem szans w walce z mężczyznami. Ulubienica Echiona przywodzi na myśl także postać Budiki, królowej Icenów, która poprowadziła w Brytanii powstanie przeciw Rzymianom. Budikę upamiętnia jeden $\mathrm{z}$ londyńskich pomników, w postaci woźnicy. 
akceptują kobiet. Jeden z nich, Arturo Llorens z Barcelony uznawał za świętokradztwo, by kobieca stopa miała tknąć areny rozsławione przez wielkich mistrzów przeszłości. W 1897 na łamach magazynu „El Arte de los Toros” pisał:

Me han merecido profunda aversión todas las mujeres que al toreo se han dedicado, y más particularmente la cuadrilla catalana, á quien la prensa taurina separatista (valga la frase), da unos bombos y un reclamo que subleva el ánimo del que medianamente se crea aficionado á nuestra hermosa fiesta nacional. Por estas razones y mil otras que por no hacerme pesado omito, considero como un sacrilegio que plantas de mujer pisen las arenas que inmortalizaron los grandes toreros antiguos y modernos (Llorens, 1897: 5).

Dziewiętnastowieczni i konserwatywni znawcy tauromachii, będący świadkami licznych zmian, również reagowali krytyką. „La Fragosa”, toreadorka, która jako pierwsza dzieliła drużynę z mężczyznami, wywołała niechęć publicysty Ángela Caamaño „El Barquero”. W zbiorze swych wierszy aż nazbyt wyraźnie określa on tradycyjną rolę kobiety, sprowadzając jej obowiązki do spraw domowych (Caamaño, 1888: 52-53):

En vez de dedicarse a planchadora

o hacerse lavandera

se dedicó al toreo esta señora

$y$, al fin, se hizo torera.

Cada cual tiene un gusto diferente

y así vamos tirando:

pero yo lo que opino es, francamente, que estaría mejor Lola fregando.

Nie brakowało w prasie innych żartów ośmieszających rolę kobiety w corridzie. W humorystycznej gazecie „Toreo cómico” pisano, że pozwalać kobietom zabijać byki, to jak kazać biskupowi, by rodził, albo funkcjonariuszowi policji, by został pomocą domową. W innym miejscu żartowano, że zapowiadana na dany dzień corrida nie odbędzie się, gdyż wiodący matador jest w niedyspozycji, bo właśnie rodzi dziecko (Schubert, 1999: 104). Inna 
gazeta, skrajnie antyklerykalny „El Motín”, zamieścił ilustrację przedstawiającą kobietę w stroju toreadora, a obok męża, modlącego się za żonę pod figurką Madonny. Ironiczny podpis głosił: „La mujer a torear y el hombre a rezar por ella”21.

Echem tego podejścia jest także forma carteles taurinos, czyli malowanych plakatów reklamujących corridę. Często, oprócz widniejącego na nim torero walczącego $\mathrm{z}$ bykiem, ważnym motywem jest stojąca $\mathrm{z}$ boku piękna kobieta, przesłonięta wachlarzem i mantylą na głowie. Kobiety były przez wieki nieodłączną ozdobą widowni, odpowiadając za doping i podziw, nie zaś za aktywny udział w walce. Ich wizerunek wykorzystywano na plakatach jako element przyciągający uwagę, podobnie jak dzisiejszy marketing wykorzystuje kobiece piękno (czy erotykę) w celach reklamowych. W 1943 roku, gdy udział kobiet w corridzie był w Hiszpanii ograniczony, José María de Cossío, autor Los Toros, obszernej historii tauromachii, cały wkład kobiet w tej dziedzinie ograniczył niesłusznie do wspomnianych mojigangas, opatrując podrozdział o toreadorach krzywdzącym tytułem Al margen de la lidia („Na marginesie walk”). W niektórych przypadkach krytykowano toreadorki za brak profesjonalizmu. "Rosarito de Colombia”, która w latach sześćdziesiątych przybyła do Hiszpanii, była bardziej ceniona za swą latynoską urodę niż umiejętności tauromachiczne. Pewną dyskredy tację przyniosła jej też współpraca z Alicią Tomás, która, nim wstąpiła na arenę, była aktorką i piosenkarką. Ostatecznie „Rosarito”, gdy coraz częściej doskwierały jej presje społeczne, w tym machismo i telefoniczne pogróżki, wymuszające na niej porzucenie kariery, zeszła $z$ areny.

Część rzymskich i hiszpańskich autorów wyraża krytyczne opinie ze względu na łamanie tradycyjnych ról płciowych. Juwenalis w swych Satyrach (2.6.247-254) kpi z żony rzymskiego obywatela, której ulubionym zajęciem są męczące treningi w pełnym uzbrojeniu. Spocona, z mieczem i tarczą w ręku, spędza dni na okładaniu ćwiczebnego słupa, a wszystko to na koszt męża:

21 „El Motín”, 5 X 1895, cyt. za: Schubert, 2010: 23. 
Quis nescit, vel quis non vidit vulnera pali?

quem cavat ad siduis sudibus scutoque lacessit atque omnes implet numeros dignissima prorsus

Florali matrona tuba, nisi si quid in illo pectore plus agitat vereaeque paratur harenae. quem praestare potest mulier galeata pudorem, quae fugit a sexu, vires amat? haec tamen ipsa vir nollet fieri... (Juvenalis, 1895: 312-313) 22 .

Oburzony poeta jasno odgranicza aktywności obojga płci, uznając sztukę wojenną za nieprzystającą kobiecie. Wskazuje, że nawet żony gladiatorów czy aktorów nie parają się gladiatorstwem ${ }^{23}$.

Z kolei autorzy chrześcijańscy nie tyle krytykowali obecność gladiatorek na arenie, co igrzyska jako takie, związane z pogańskim kultem oraz pozbawianiem życia ludzkiego (Tert. De spect. 4.3; Aug. Conf. 3.8.16; 6.8.13). Św. Ambroży, komentując mit o Artemidzie (Virg. 3.2.6), nazywa boginię łowów „venatrix sane optima, non ferarum, sed libidinum” (Ambrosius, 2018: 222) ${ }^{24}$. Wyznaczając wzorce dziewictwa bądź macierzyństwa dla chrześcijańskich kobiet, posługuje się w De virginibus obrazem pogańskiej łowczyni jako zgubnego obiektu pożądania bogów i ludzi.

Podobnie krytykowane były toreadorki. Osiemnastowieczna rejoneadora, Francisca García, zdobywszy uznanie w Andaluzji,

22 „Któż nie zna, albo kto nie widział pociętego słupa [do ćwiczeń], który sieką i biją, czy to mieczem czy tarczą wykonując wszystkie chwyty. To one dmą w tubę na cześć matki Flory, albo może w swej piersi zamyślają więcej, przygotowując się na prawdziwą arenę. Jaką godność może okazać kobieta zakuta w hełm, która ucieka od swej płci, pragnąc męskiej siły? Jednak wcale nie chce być mężczyzną... " (tłum. D. B.).

23 Juwenalis sugeruje, że kobieta ta ćwiczy, by wystąpić we Floraliach. Podczas tego wiosennego święta udział w przedstawieniach brały nagie prostytutki, tutaj naśladujące gladiatorów (Scullard, 1982: 110).

24 „doskonałą łowczynią, bez wątpienia, jednak nie dzikich zwierząt, lecz pożądania” (tłum. D. B.). 
domagała się, by walczyć w Pampelunie, ale odmawiano jej wielokrotnie, uznając to za nieprzyzwoite. Wspomniana już „Pajuelera” spotykała się z krytyką współczesnych intelektualistów, zwłaszcza ze strony przedstawicieli katolickiego oświecenia. Uczeni tacy jak Benito Jerónimo Feijóo e Montenegro (1676-1764), czy ojciec Martín Sarmiento (1695-1772) sądzili, że obecność kobiet na arenie kłóci się z tradycyjną kobiecą pobożnością. Ten ostatni pisał:

Este fenómeno ha sido la ignominia del devoto femíneo sexo, que tiene adherente la compasión, y la afrenta del indiscreto sexo barbado, que toleró y dio licencia para que saliese al público semejante monstruosidad. Cotéjese esa Pajuelera con el ejercicio de las niñas gallegas, que, puestas a la frente de una vaca o buey manso, están hilando todo el día y cuidando que ese ganado no eche la lengua a las mieses que tiene a boca. ¿Qué ha sido aquello sino ridiculizar la fiesta de los toros? (cyt. za: Hernández, 2008).

Uczeni ci traktowali udział w corridzie jako zjawisko burzące tradycyjny podział ról płciowych oraz godzące $w$ tradycyjną religię. Niektórzy z nich w ogóle uważali corridę za moralnie negatywną, również dla widza ${ }^{25}$.

\section{4.}

\section{Regulacje prawne}

Prawdziwym powodem oburzenia tych i innych autorów jest często nie tyle kwestia płci, co raczej pochodzenia społecznego. Wiemy, że gladiatorów rekrutowano spomiędzy osób o niskim statusie społecznym, w tym niewolników. Wysoko urodzonym Rzymiankom (podobnie jak Rzymianom), wypadało uczest-

25 Z krytyką igrzysk wystąpili już antyczni filozofowie i teologowie, jak św. Augustyn (Conf. 3.8.16; 6.8.13), Seneka (Ep. 95.33; Constant. 16.2; Ben. 2.34) czy Cyceron (Tusc. 2.41). 
niczyć w igrzyskach wyłącznie w charakterze widza. Występowanie na arenie, aktorstwo czy prostytucja (niezależnie od płci), były zajęciami właściwymi dla osób o niskim statusie społecznym ${ }^{26}$. Kobiety zmuszane do walki, lub dobrowolnie decydujące się na taką formę zarobku, widnieją w tekstach jako mulier ${ }^{27}$. Gdy mowa o wysoko urodzonych obywatelkach, autorzy częściej używają terminu femina: żonach i córkach senatorów czy innych wysoko postawionych obywateli (Tac. Ann. 15.32; Suet. Dom. 4.1). Niektóre z nich, jak widzieliśmy, dla zabawy chwytały za miecz i w zaciszu domowym spędzały czas na treningu. Uchodziło jednak za skandal i groziło zniesławieniem (infamia), jeśli którakolwiek z nich zdecydowałaby się wystąpić publicznie, by dostarczać rozrywki dla ludu.

Dlatego też pojawiły się pewne regulacje prawne, mające zapobiec podobnym wypadkom. Już w czasach Augusta senatus consultum $\mathrm{z}$ roku 11 n.e. zabronił występowania na arenie wolnym kobietom poniżej dwudziestego roku życia (Pastor, Mañas, 2012: 128). Osiem lat później podobna ustawa z Larinum, rozszerzyła zakaz na córki, wnuczki i prawnuczki senatorów oraz żony, córki i wnuczki ekwitów (19 n.e.) oraz zabraniała także wykonywania zawodu aktora (Levick, 1983: 97-115; Lebek, 1990: 60). To właśnie w świetle stanu społecznego rozpatrywać należy krytykę większości historyków rzymskich: nie byli oni raczej przeciwnikami gladiatorek jako takich, lecz polityki cesarzy i upadku obyczajów. Tacyt (Ann. 15.32) opisując czasy Nerona, zwraca uwagę, że obywatele i obywatelki Rzymu brali udział w wyścigach rydwanów, walkach gladiatorskich czy venationes: „Spectacula gladiatorum idem annus habuit, pari magnificentia ac priora. Sed feminarum inlustrium senatorumque plures per arenam foedati sunt" 28 . Po-

26 To dlatego Juwenalis wyśmiewa niejaką Eppię, zakochaną w gladiatorze, która zdecydowała się z nim na ucieczkę (Juv. 6.82).

27 Petron. Sat. 45.738; Tac. Ann. 14.15; CIL IX, 2237 (Coleman, 2000: 498; Pastor, Mañas, 2012: 135).

28 „Tego samego roku zorganizował igrzyska gladiatorów, tak wspaniałe jak te w przeszłości. Jednakże wiele znamienitych kobiet oraz senatorów zhańbiło się poprzez arenę" (Tacitus, 1906; tłum. D. B.). 
dobny opis i oburzenie wyraża Kasjusz Dion (61.17.3) ${ }^{29}$. Septymiusz Sewer w roku 200 n.e. zabroni wszystkim kobietom, bez względu na stan społeczny, udziału w pojedynkach. Decyzję tę podjąć miał z powodu negatywnej reakcji publiczności na zaprezentowane w Rzymie atletyczne zapasy kobiet typu „monomachia”. Zakaz miał zapobiec powstawaniu poruszenia wśród publiczności ${ }^{30}$.

Hiszpańską corridę próbował regulować Kościół. W latach 1215-1316 obowiązywał zupełny zakaz corridy, a papież Pius V (1567) zabraniał parania się tauromachią szlachetnie urodzonym chrześcijanom, zwłaszcza duchownym i żołnierzom. Po ośmiu latach powrócono do dawnych nawyków: na ogół stanowisko Kościoła było bezsilne wobec obyczaju, który każde święto (także kościelne) kazał uświetniać corridą. Obyczaj ten jednak nie przewidywał aktywnego udziału kobiet, których droga na arenę była wyjątkowo długa. Nieliczne, które pragnęły publicznie walczyć z bykami, napotykały trudności natury prawnej i obyczajowej. José Daza w Precisos manejos wspomina, że pewnej kobiecie wysokie urodzenie nie pozwalało wziąć udziału w walce. Miała skarżyć się na słabą płeć kobiecą, aż do dnia gdy zobaczyła znaną nam już „Pajuelerę” (Daza, 1999: 102). To czasy, gdy corrida była jeszcze zajęciem na poły szlacheckim. Kolejne zakazy, najczęściej krótkotrwałe, wprowadzili Karol III (w 1771 roku) oraz Karol IV w 1805 roku (Kowalski, Rodríguez Núñez, 1992: 93). Józef Bonaparte, osadzony na tronie hiszpańskim z ramienia napoleońskiej Francji, cofnął zakaz corridy, starając się tym gestem przypodobać okupowanemu narodowi. Najcięższe czasy dla hiszpańskich

29 Kasjusz Dion opisuje igrzyska w roku 59; Tacyt być może te same igrzyska świadomie datuje na 63 rok, podkreślając tym szczególny upadek obyczajów w czasach Nerona (Brunet, 2004: 145).

30 Autor wspomina, że zapasy te miały wowołać wśród publiki śmiech z atletek oraz kobiet z klasy senatorskiej. Możliwe, że w tej (lub wcześniejszych) walkach brały udział kobiety z wyższych klas, co spotkało się ze złym odbiorem. Możliwe więc, że cesarz już wcześniej zamierzał zabronić walk gladiatorek, a reakcje podczas wspomnianych igrzysk posłużyły mu za pretekst (Cass Dion, 76.16; por. Potter, 2010: 407). 
toreadorek przypadły na przełom XIX i XX wieku. Konserwatywna polityka władz i prawicowe nastroje społeczne wywoływały ogólną niechęć wobec lekkich obyczajów praktykowanych w salach koncertowych, kabaretach i teatrach. Coraz częściej mężczyźni odmawiali współudziału w corridzie z kobietami czy nawet występowania na arenach, na których wcześniej występowały kobiety. Ostatecznie w 1908 minister Juan de la Cierva wprowadził w życie dekret królewski, który na dwadzieścia cztery lata zakazał kobietom czynnego udziału w corridzie. Tak zwracał się do lokalnych władz:

La opinión pública ha protestado en varias ocasiones contra la práctica que se va introduciendo en las plazas de toros de que algunas mujeres tomen parte en la lidia de reses bravas, y si bien se alega que la ley no lo prohíbe expresamente, el hecho en sí constituye un espectáculo impropio y tan opuesto a la cultura y a todo sentimiento delicado, que en ningún caso deben las autoridades gubernativas permitir su celebración, como acto que ofende a la moral y a las buenas costumbres (cyt. za: Crivell, 2016).

Ten trudny okres najlepiej ilustruje dramatyczna historia Marii Salome „La Reverte”. Już w wieku dziecięcym przezywano ją chłopczycą, la marimacho. Czas prosperity na arenie przerwał jej wspomniany wyżej dekret z 1908 roku. Zdecydowała jednak kontynuować karierę pod męskim nazwiskiem Agustín Rodríguez, wywołując tym samym podejrzenia o hermafrodytyzm. Nacisk społeczny sprawił jednak, że porzuciła karierę. Wycofana, pędziła życie, pracując jako stróż w kopalni w rodzinnym Jaén (Román, 2015). Z nastaniem Drugiej Republiki chwilowo zniesiono zakaz. Powrót „La Reverte” po dwudziestu latach przerwy, wówczas sześćdziesięciolatki, przyniósł jej w świecie tauromachii wyłącznie porażkę. Warto podkreślić, że zniesienie zakazu nie nastąpiło wraz ze zmianą ustroju. Juanita Cruz, która podczas swej kariery walczyła u boku samego Manolete, naciskała na rząd, przypominając, że republikańska konstytucja gwarantuje równość płci i wolność (Fernández Casado, 2014). W 1934 roku pozwolono kobietom wrócić na arenę, co od razu przyniosło wielkie 
sukcesy, jednak na krótko. O ile w 1935 w Madrycie brakowało biletów na corridy z udziałem Juany Cruz, o tyle już rok później prasa ośmieszała ją i jej koleżanki, zamieszczając zdjęcia z niefortunnych momentów walk. Republikanka wyemigrowała, by kontynuować karierę w Meksyku. Co ciekawe, choć nosiła strój podobny do toreadorów, zamiast spodni wkładała spódnicę.

Również rządy Franco nie były przychylne toreadorkom. Aż do 1974 roku obowiązuje oficjalny zakaz publicznych walk „pieszych" (toreo a pie). Oznacza to, że kobiety mogły występować w Hiszpanii tylko na podrzędnych, prywatnych arenach, lub też walczyć konno jako rejoneadoras ${ }^{31}$. Realia epoki oddaje historia Conchity Cintrón, zwanej później „La diosa de oro” (Złota bogini), najpopularniejszej toreadorki wszech czasów. Urodzona w Chile, zdobyła wręcz legendarną sławę na arenach Peru, Meksyku, Francji, Portugalii i Maroka, marząc o stoczeniu walki na arenie hiszpańskiej. W 1945 roku pozwolono jej tam wyłącznie na walkę konną. Cztery lata później, po konnej walce w Jaén, poprosiła przewodniczącego corridy o możliwość dokończenia walki pieszo. Gdy odmówił, prowokacyjnie zeszła na arenę i zadała szarżującemu na nią bykowi sfingowaną ,śmierć”, pozwalając, by przemknął pod szpadą. Mimo wiwatów tłumu, po zejściu z areny aresztowano ją za złamanie prawa. Orson Welles, we wprowadzeniu do jej pamiętników Memoirs of a Bullfighter, pochwali ten „wybuch wspaniałego przestępstwa”. O samej Cintrón napisał: „Her record stands as a rebuke to every man of us who has ever maintained that a woman must lose something of her femininity if she seeks to compete with men" (cyt. za: Sherwood, 2002: 177).

Nawet słynne encierros w Pampelunie kobiety mogły wyłącznie obserwować. Jeszcze w latach osiemdziesiątych zdarzały się przypadki, że kobiety rzucały się w gonitwę, raczej manifestując swe prawa, niż okazując zainteresowanie bykami. Dopiero późniejsze czasy pozwoliły na zabłyśnięcie takim gwiazdom tauro-

31 Podejrzewa się, że polityka Franco miała na celu nie tyle chronienie kobiet, co niedopuszczenie, by w przypadku odniesienia ran (w wyniku cornady, tj. nabicia na róg, ubodnięcia), medycy nie odsłonili publicznie kobiecej nagości. 
machii jak Cristina Sánchez, Mari Paz Vega czy Hilda Tenorio, Meksykanka. Po zakazach corridy na Wyspach Kanaryjskich (1991) i w Katalonii (2012), wydaje się, że to Meksyk będzie mekką tauromachii, może również kobiecej.

\section{5.}

\section{Wnioski końcowe}

Przyjrzeliśmy się obecności kobiet na arenach starożytnego Rzymu oraz hiszpańskich. Łączy je wiele podobieństw. Po pierwsze, igrzyska i corrida to sfery silnie zmaskulinizowane. Obecność gladiatorek i toreadorek jest wystarczająca, by mówić o zjawisku, lecz w obu przypadkach stanowią one swego rodzaju rzadkość, która prowokuje do ambiwalentnych sądów. Z jednej strony Rzymianie, jak i w ogóle większość narodów, cenili męstwo (łac. virtus, hiszp. valor), w którym niektóre kobiety mogły mieć udział. $Z$ drugiej strony przypisywane od wieków role społeczne sprawiły, że to mężczyzn łączy się ze sprawami wojny, zaś kobietom przypisuje się funkcję obserwatorek, strażniczek ogniska domowego. Chęć przekroczenia tych patriarchalnych norm, burząca pewien ustalony porządek społeczny, wywoływała u Rzymian, jak i u Hiszpanów, dość ostre reakcje poetów i myślicieli. Warto zauważyć próby marginalizacji czy ośmieszenia kobiet areny (Juwenalis, Cossío). Podkreślmy, że w społeczeństwie rzymskim igrzyska były domeną osób o niskim statusie społecznym, zaś w corridzie zjawisko to ewoluowało od zajęcia arystokracji po fiestę ludową i narodową. O ile Rzymiankom nie pozwalał na udział w publicznych występach zwłaszcza wysoki status społeczny, o tyle w społeczeństwie hiszpańskim była to niemal zawsze kwestia kulturowego postrzegania płci. Opinie ojca Sarmiento czy Feijóo potwierdzają, że pojmowanie corridy jako złego obyczaju wiązało się także z religią katolicką, kształtującą tradycyjne role kobiece, a często w ogóle przeciwną corridzie. Dlatego też regulacje prawne zastosowane tak w Imperium Rzymskim, jak w Hiszpanii, choć dotyczyły podobnej sfery 
kultury, opierały się jednak na nieco odmiennych przesłankach społecznych, religijnych czy kulturowych. Kobiety areny są postaciami pozornie drugo- a może nawet trzecioplanowymi na tle męskiego żywiołu, który przez wieki dominował w tej dziedzinie. Ich fenomen i paradoks być może polega na tym, że przez swą rzadkość i niecodzienność wydają się nieraz przesłaniać blask dumnych gladiatorów i toreros. Być może to nie brak umiejętności nie pozwalał kobietom częściej gościć na arenie, lecz ukryta obawa mężczyzn przed marginalizacją. Na zakończenie chciałbym przytoczyć pewną refleksję hiszpańskiego polityka i badacza sanfermines z Pampeluny, który zauważył, że obecność kobiety na arenie zawsze odwróci uwagę publiki, pozostawiając w tle nawet najzdolniejszych matadorów:

En el mundo del cine hay un consejo clásico para los actores: no trabajar con niños ni animales, pues si tienen un papel destacado en una película monopolizan la atención del público y eclipsan al resto del reparto. El mismo riesgo acecha con una mujer torero; sea el cartel que sea, el público prestará atención preferente a la torera y los otros dos espadas, por importantes que sean, se convierten en teloneros o comparsas. (Izu, 2007: 67)

\section{Bibliografia}

Alberge, D. (2000): "Woman Gladiator Found Buried in London". The Times, 13.09: 3.

Ambrosius (2018): "De Virginibus ad Marcellinam Sororem Sua Libri Tres”. W: Documenta Catholica Omnia, Vol. MPL016, http://www.documentacatholicaomnia.eu/04z/z_0339-0397_Ambrosius_De_Virginibus_Ad_Marcellinam_Sororem_Sua_Libri_Tres_MLT.pdf.html [25.05.2018].

Athenaeus (1928): The Deipnosophistae of Athenaeus, Vol. II. Cambridge: Harvard University Press/Loeb Classical Library.

Barbarzak, D. (2017): „Rzymskie igrzyska i hiszpańska corrida. Rys porównawczy obu tradycji na wybranych przykładach”. Symbolae Philologorum Posnaniensium 2 (26): 19-43.

Brunet, S. (2004), Female and Dwarf Gladiators, „Mouseion”, 4: 145-170. 
Brunet, S. (2014): "Women with Swords. Female Gladiators in the Roman World”. W: P. Christesen, D. G. Kyle (eds.), A Companion to Sport and Spectacle in Greek and Roman Antiquity. New Jersey: Wiley-Blackwell.

Caamaño, A. (1888): Cabezas, cabezillas y cabezotas. Colección de toreros buenos, medianos y malos. Madrid: Imprenta Militar.

Cela, C. J. (2017): San Camilo, http://www.acanomas.com/Libros-Clasicos/48572/San-Camilo-1936-(Camilo-Jose-Cela).html [20.11.2017].

Coello Ugalde, J. F. (2013): "Las mojigangas: aderezos imprescindibles y otros divertimentos". Taurinas mexicanas 29, https://ahtm.wordpress.com/2013/08/25/ las-mojigangas-aderezos-imprescindibles [20.11.2017].

Coleman, K. (2000): "Missio at Halicamassus". Harvard Studies in Classical Philology 100: 498.

Crivell, C. (2016): María Salome 'La Reverte' y linares, http://sevillatoro. es/?p=223604 [20.05.2018].

Daza, J. (1999): Precisos manejos y progresos del arte del toreo. Sevilla: Universidad.

Diccionario de la lengua española, hasło varón, Real Academia Española, http://dle.rae.es/?id=bOJpDhG [20.05.2018].

Feiner, M. (1995): Mujer en el mundo del Toro. Madrid: Allianza.

Feiner, M. (2017): Mujer y tauromaquia. Barcelona: Bellaterra.

Fernández Casado, A. (2014): Juana Cruz y la lucha por su derecho a torear, https://www.taurologia.com/juanita-cruz-lucha-derecho-torear-3171. htm [20.11.2017].

Fernandez, L. A. (2008), Las mujeres toreras, https://torostarifa.blogspot. com/2008/01/las-mujeres-toreras.html [20.11.2017].

Grant, M. (1971): Gladiators. Harondsworth: Penguin.

Izu, M. (2007): Sexo en sanfermines y otros mitos festivos. Navarra: Sehats.

Jackson, R (2000): “Gladiators in Roman Britain”. British Museum Magazine 2000, 38: 16-21.

Juvenalis (1895): D. Junii Juvenalis Saturarum Libri V, t. 1, oprac. L. Friedlaender. Leipzig: Verlag von S. Hirzel.

Kasjusz Dion (1925): Roman History by Cassius Dio, Vol. VIII. Cambridge: Harvard University Press/Loeb Classical Library.

Korpanty, J. (2007): Mały słownik łacińsko-polski. Warszawa: Wydawnictwo Naukowe PWN.

Kowalski, K.; Rodriguez Núñez, M. (1992): Corrida. Warszawa: Ludowa Spółdzielnia Wydawnicza. 
Kyle, D.G. (2004): A Companion to Sport and Spectacle in Greek and Roman Antiquity. Chichester: Wiley-Blackwell.

Lebek, D. (1990): „Standeswilrde und Berufsverbotunter Tiberius: Das SC der Tabula Larinas". Zeitschrift für Papyrologie und Epigraphik 81: 37-96.

Levick, B. (1983): "The Senatus Consultum from Larinum". Journal of Roman Studies 73: 97-115.

Llorens, A. (1897): “El toreo mujeril”. El Arte de los Toros 15 (75): 5, http:// bibliotecadigital.jcyl.es/bdtau/es/catalogo_imagenes/grupo.cmd? path=10100116 [20.05.2018].

Madariaga, B. Valbuena, C. (1976): Cara y Máscara de José Gutiérrez-Solana. Santander: Ediciones de Librería Estvdio.

Mañas, A. (2011): "New evidence of female gladiators: the bronze statuette at the Museum für Kunst und Gewerbe of Hamburg". International Journal of the History of Sport 28 (18): 2726-2752.

Marcjalis (2015): Księga widowisk, tłum. K. Różycka-Tomaszuk. Wrocław: Instytut Studiów Klasycznych, Śródziemnomorskich i Orientalnych Uniwersytetu Wrocławskiego.

Martialis (2018): M. Valeri Martialis, Epigrammaton (liber de spectacvlis), http://www.thelatinlibrary.com/martial/mart.spec.shtml [20.05.2018].

Mateo Gómez, I. (2003): "El artesonado del claustro del monasterio de Silos". Studia Silensia 4 (28): 255-296.

McCullough, A. (2008): "Female gladiators in imperial Rome: literary context and historical fact". The Classical World 2 (101): 197-210.

Murray, S. (2003): "Female Gladiators of the Ancient Roman World”. Journal ofCombative Sports, http://ejmas.com/jcs/jcsart_murray_0703.htm [27.01.2017].

Pastor, M., Mañas A. (2012): "Munera gladiatorum. Mujeres gladiadoras". Florentia iliberritana.

Petronius (2018): C. Petronii Satyricon Liber, http://www.thelatinlibrary.com/ petronius1.html [28.05.2018].

Potter, D. S. (2010): "Spectacle”. W: D. S. Potter (ed.), A Companion to the Roman Empire. Oxford: Blackwell Publishing.

Pringle, H. Broad, J. (2001): “Gladiatrix”. Discover, http://discovermagazine. com/2001/dec/featglad [20.11.2017].

Propertius (1816): Sex. Aurelii Propertii Carmina, oprac. C. Lachmanus. Lipsiae: Gerhard Fleischer. 
Revista de estudios de antigüedad clásica 23: 127-151.

Román, M. (2015): “ ‘La Reverte', una mujer torera que era varón”. Libertad Digital, 8.05, http://www.libertaddigital.com/cultura/toros/2015-05-08/la-reverte-una-mujer-torera-que-era-varon-1276547496 [10.11.2017].

Scullard, H. H. (1982): Festivals and Ceremonies of the Roman Republic. Ithaca/New York: Cornell University Press.

Schubert, A. (1999): "Gender”. W: A. Schubert, Death and Money in the Afternoon. The History of Spanish Bullfight. Oxford/New York: Oxford University Press.

Schubert, A. (2010): “El toreo en la historia española”. Revista de Estudios Taurinos 28: 15-41.

Sherwood, L. A. (2002): Yankees in the Afternoon. An llustrated History of American Bullfighters. Jefferson/London: McFarland.

Spanos, B. (2017): Flashback: Beyoncé, Britney Spears and Pink Rock a Roman Arena, Cover Queen, „Rollingstone”, 5 April 2017, https://www.rollingstone.com/music/news/flashback-beyonce-britney-spears-pink-rockroman-arena-cover-queen-w429457 [20.05.2018].

Statius (2018): P. Papini Statii Silvae, red. E. Marastoni. Leipzig: Teubner, http://latin.packhum.org/loc/1020/2/6\#6 [20.05.2018].

Suetonius (1913): De Vita XII Caesarum C. Suetonii Tranquilli, Cambridge: Harvard University Press/Loeb Classical Library.

Swetoniusz (1965): Gajus Swetoniusz Trankwillus, Żywoty cezarów, tłum. J. Niemirska-Pliszczyńska, Wrocław/Warszawa/Kraków: Zakład Narodowy im. Ossolińskich.

Tacitus (1906): Annales ab excessu divi Augusti.Cornelius Tacitus, oprac. Ch. D. Fisher. Oxford: Clarendon, http://www.perseus.tufts.edu/hopper/ text?doc=Tac.+Ann.+15.32\&fromdoc=Perseus\%3Atext\%3A1999.02.0077 [20.05.2018]. 